\title{
Influence of nature and level of concentrate in the diet on in sacco degradation of two different hays
}

\author{
P Nozière 1, C Martin 1, C Durier 2, B Michalet-Doreau 1 \\ 1INRA, Station de Recherches sur la Nutrition des Herbivores, Theix, 63122 St-Genès-Champanelle; \\ 2INRA, Biométrie, 78026 Versailles cedex, France
}

The supplementation of forage diets with readily fermentable carbohydrates is known to depress ruminal fiber digestion (Poore et al, 1990, J Anim Sci, 68, 2965-2973). The decrease in degradation may depend on the nature of both the concentrate and the forage. The purpose of this work was to investigate the amplitude of this depressing of a high fibber and a high starch concentrate on in sacco degradation of two different hays.

Three fistulated sheep were successively fed twice daily $1.2 \mathrm{~kg} \mathrm{DM} /$ day of hay with $0 \%$ concentrate (diet $\mathrm{H}$ ), 30 or $60 \%$ beet pulp (diets $\mathrm{P} 30$ and $\mathrm{P} 60$ ), and 30 or $60 \%$ corn (diets $\mathrm{C} 30$ and $\mathrm{C} 60$ ). Degradability of DM and NDF of two hays $(\mathrm{H}+$ and $\mathrm{H}-)$ was studied by the nylon bag technique. NDF, ADF and ADL contents were respectively $63.5,33.9$ and $4.8 \% \mathrm{DM}$ for $\mathrm{H}+$, and $66.2,42.0$ and $8.4 \% \mathrm{DM}$ for $\mathrm{H}$-.

Decrease in DM degradability of hays induced by concentrate was linked to decreased NDF degradability. Consistent with Carey et al (1993, J Anim Sci, 71, 2260-2269), this decrease did not depend on the nature of the concentrate when supplementation was low (30\%). At higher supplementation levels
(60\%), the depressing effect of concentrate on DM degradability was greater with beet pulp (-12.6 points) than with corn ( -9.0 points), but this difference was not observed on NDF (-12.4 vs -11.6 points).

Decrease in NDF degradation induced by a $60 \%$ supplementation was greater for $\mathrm{H}+$ (-13.6 points) than $\mathrm{H}$ - $(-10.4$ points). This difference in response between forages cannot be attributed to their total NDF content, which was similar. The same conclusion can be drawn from comparison of results reported by Lindberg (1981, Swedish J Agric Res, 11, 159169) and Poore et al (1990, J Anim Sci, 68, 2965-2973). Differences between the forages could be more likely due to the nature of celwall components. The cell walls of $\mathrm{H}+$ are characterised by lower cellulose and lignin contents than those of $\mathrm{H}-$, and by a higher degradability ( 33.5 vs $23.2 \%$ ). The depressive effect of concentrate supplementation is thus greater for less lignified and more degradable forage. The modifications of microbial activity caused by supplementation would therefore have less impact on cell-wall degradation when this is itself strongly limited by the specific characteristics of the forage.

\begin{tabular}{|c|c|c|c|c|c|c|}
\hline Diet & & $\mathrm{H}$ & P30 & $\mathrm{P} 60$ & $\mathrm{C} 30$ & $\mathrm{C} 60$ \\
\hline DM degradability & $\begin{array}{l}\mathrm{H}_{+} \\
\mathrm{H}-\end{array}$ & $\begin{array}{l}50.1 \\
40.5\end{array}$ & $\begin{array}{l}43.6 \\
37.2\end{array}$ & $\begin{array}{l}36.2 \\
29.3\end{array}$ & $\begin{array}{l}44.9 \\
37.3\end{array}$ & $\begin{array}{l}41.1 \\
31.6\end{array}$ \\
\hline NDF degradability & $\begin{array}{l}\mathrm{H}+ \\
\mathrm{H}-\end{array}$ & $\begin{array}{l}33.5 \\
23.2\end{array}$ & $\begin{array}{l}26.2 \\
18.7\end{array}$ & $\begin{array}{l}19.2 \\
12.7\end{array}$ & $\begin{array}{l}25.3 \\
19.0\end{array}$ & $\begin{array}{l}20.6 \\
13.0\end{array}$ \\
\hline
\end{tabular}

